\title{
THE IMPACT OF GLOBAL CHALLENGES ON “GREEN" TRANSFORMATIONS OF THE AGRARIAN SECTOR OF THE EASTERN PARTNERSHIP COUNTRIES
}

\author{
Svetlana Kovalchuk ${ }^{1}$, Alina Kravchuk ${ }^{2}$
}

\begin{abstract}
The restructuring of the economy of countries of the Eastern Partnership with the EU requires new ways of implementation, which are based on the principles of ecologization, with due consideration of integrated indicators of strategic environmental assessment and balanced resource-efficient, environmentally-friendly production. Subjectmatter: theoretical and practical principles of "green transformations" as a modern direction of the world economy, based on the harmonious use of innovative technologies and the natural environment. Purpose. The main purpose of the publication is to assess how the "green" growth strategy is implemented in the development of the agrarian sector, the demonstration of the importance and efficiency of green growth indicators and their practical application. The realization of the purpose led to solving the research tasks: to substantiate the necessity of forming a change in the agrarian paradigm in the countries of Eastern Europe, to analyse trends of the introduction of green growth, to prove the importance of the efficiency of using the green growth indicators. Methodology. The basis of the research methodology is the dialectical method, which involves the connection theory and practice, the principles of knowledge of the real world, the determinancy of phenomena and interaction processes of external and internal. In order to achieve the purpose and solve the tasks, the following methods were used: system-structural - in the study of the sustainable development of the agrarian sector; abstract-logical - when forming, generalizing, and analysing tendencies of adaptation of the Eastern Partnership countries to the Green Growth Concept; comparative for comparing the factual data with the theoretical ones and characteristics of changes in time of indicators. As well as the methods of description and comparison were used to determine the vectors for the introduction of green growth in the countries of the Eastern Partnership. Results. New challenges for the world economy make it necessary to modernize the economy solely for ensuring sustainable development through green growth. According to the results of the analysis, the essence of "green"transformations of the agrarian sector was established, which proves the regularity of the inclusion of the ecological factor in the system of basic socio-economic indicators of the development of Eastern European countries. At the same time, on the basis of the generalization of the theoretical provisions, it was found that green growth stimulates competitive, innovative, investment activities, which can lead to new sources of economic growth. For the qualitative expression of the indicators of green growth, the dynamics of GDP of the countries of the Eastern Partnership with the EU and indicators of rational use of natural resources were analysed and summarized. Conclusions. Given the above, the necessity to use indicators of green growth in statistical information is proved, which allows reducing risks of economic growth; reducing the risk of conflicts caused by lack of resources; balancing the ecological imbalance of rural areas. The practical significance of the results obtained is the possibility of their use in the formation of statistical information, and the indicator of the efficiency of agricultural land use makes it possible to trace environmental and resource productivity, multi-factor productivity, dynamics of land use, life expectancy. The research results can be used as an analytical and informational basis for further scientific developments in the field of research on the impact of green transformations on the sustainable development of the agrarian sector.
\end{abstract}

Key words: natural capital, environmentally-friendly growth, green growth indicators, green growth strategies, sustainable agriculture, green growth monitoring.

JEL Classification: F43, O13, Q29

\footnotetext{
Corresponding author:

${ }^{1}$ Vinnytsia National Agrarian University, Ukraine.

E-mail: koval4uk@vsau.vin.ua

ORCID: https://orcid.org/0000-0001-7590-4467

${ }^{2}$ Vinnytsia National Agrarian University, Ukraine.

E-mail:mel@vsau.vin.ua

ORCID: https://orcid.org/0000-0002-6160-3767
} 


\section{Introduction}

The transformational processes of the agrarian sector are characterized by significant changes, which meant the change of the agrarian paradigm and the formation of a new agroecological policy. The result of this theory is recognition of a market model for the development of the agrarian sector, its competitiveness, and the recognition of the industry as the most sensitive structural element of the economy, which instantly responds to fluctuations of external factors.

Modern models of the development of the world economy cannot take into account the results of complex causal relationships between economic assets and natural capital while ensuring their effective use and reproduction. Along with that, modern business models are putting society at high risk of growth inhibition. The emergence of risks increases with the wasteful use of natural capital, which results in the destruction of a whole sector of economically important agroecosystem infrastructure. The limitation or apathy of the implementation of measures aimed at preserving this capital will inevitably lead to an increase in the cost of its replacement (Kurinets, Kharichkov, 2007). The transition to environmentally-friendly growth increases the economic benefits and revenues from the use of natural capital. At the same time, current revenues from this capital should be used with considerable caution so that their use encourages the growth of other forms of capital (primarily human and productive ones) (Ecologization of the economy in the EU Eastern Neighbourhood countries).

In fact, this proves that the determining factor in the transformational processes of the world economy is the introduction of the principles of a green economy and green growth (Kvasha, 2015). Even given all the importance of economic growth, its ultimate goal is to ensure the improvement of the living conditions of every person today and in the future. An objective need keeps up to date to study the impact of green transformations on the development of the agricultural sector of the countries of the Eastern Partnership with the EU.

The scientific novelty consists in substantiation of the expediency of application of green growth indicators at the formation of the statistical information, in particular, the indicator of agricultural land use efficiency, which allows tracing ecological and resource productivity, is proposed.

The analysis of existing issues on green growth problems is the subject of numerous scientific studies; however, the issue of green growth in agricultural development is not sufficiently highlighted. It is worth looking at the study of this problem by the following scholars: Bukrynskyi B. V., Halushkina T. P., Heiets V. M., Kvasha T. K., Kurinets L. Ye., Musina L. A., Zegar J. S. and others.

\section{External factors of influence on green growth}

The decisive problem of economic growth is increasingly dependent on the formation of international decisions in the field of ecology, on the conditions of integration of countries into the international economic space, and the reaction of national economies to integration processes. The integration processes contribute to the manifestations of the national specificity, stimulate its development, determine the place of the country in the international division of labour, the level of competitiveness of products, and providing opportunities for meeting the needs of society. In its turn, interdependent links between countries are formed, which creates a significant sectoral impact on the structure of production within the country, taking into account its specificity.

According to scientists-economists, in order to achieve sustainable development goals, in the transformational conditions of the world economy, a new approach must be applied that takes into account compromises and synergistic interaction between sectors and components of sustainability (Ecologization of the economy in the EU Eastern Neighbourhood countries).

That is why, in order to determine the influence of external factors on the formation of the Green Growth Strategies of the Eastern Partnership countries, we use a PESTEL analysis. With the help of which we will identify the political, economic, social, technological, legal, and environmental factors that underlie the formation of the Green Growth Strategies of the Eastern Partnership countries (Table 1).

Note that the positions discussed in the table characterize the structure of the economy of Eastern European countries, which is distinguished by asymmetric development towards the branches of agriculture, which is most sensitive to external factors. Eastern European countries have favourable natural conditions for the functioning of natural capital, as a rule, they export raw materials and agricultural products. The raw material export-oriented direction is marked by low value-added, which is an indisputable fact of the need to find new ways to generate income other than the export of raw materials. Taking into account the experience of OECD member countries, modernizing the economy, the main vector of which is green growth, has a positive effect of growth as evidenced by improved welfare in the countries (Ecologization of the economy in the EU Eastern Neighbourhood countries).

The green growth policy in Eastern European countries is closely linked to the actual development goals of the countries' economies, in particular, the diversification of the economy, the increase of production efficiency, which affects competitiveness in international markets. In addition, environmentalization affects the export potential of the country and the creation of new jobs. 
Table 1

PESTEL analysis of the influence of external factors on the formation of the Green Growth Strategies of the Eastern Partnership countries

\begin{tabular}{|c|c|c|c|}
\hline Pol & $\mathrm{P}$ & & $\mathrm{E}$ \\
\hline \multicolumn{2}{|l|}{$\begin{array}{l}\text { Integration changes in country policies; } \\
\text { Accession to the WTO has not created the desired favourable } \\
\text { conditions for economic growth; } \\
\text { Fixing the international image of countries that adopt the rules and } \\
\text { principles of international trade; } \\
\text { Eastern European countries are considered key components of } \\
\text { geostrategy of Western Europe; } \\
\text { Lack of sufficient experience in the development of the economy, } \\
\text { which is not ready for a liberal and cruel regulation of the conditions } \\
\text { of world trade. }\end{array}$} & \multicolumn{2}{|l|}{$\begin{array}{l}\text { The sharp decline in commodity prices in countries of Western } \\
\text { Europe; } \\
\text { Countries have adopted WTO strict tariffs for agricultural products; } \\
\text { No transition to a post-industrial development model has been made; } \\
\text { Replacement of protectionist measures by subsidizing, which may } \\
\text { lead to deformations in the agrarian sector; } \\
\text { The slowdown in the rate of foreign direct investment; } \\
\text { With higher taxation, the emergence of the shadow sector and, as a } \\
\text { consequence, the growing prices for production; } \\
\text { Reduced competitiveness of processing agricultural enterprises. }\end{array}$} \\
\hline Social & $\mathrm{S}$ & Technological & $\mathrm{T}$ \\
\hline $\begin{array}{l}\text { Integration into world markets, preserving national interests; } \\
\text { Low living standards in the post-industrial period; } \\
\text { The necessity of training of skilled personnel, in combination with } \\
\text { pilot projects of SEA; } \\
\text { Harmonization of production and trading activities with the } \\
\text { opportunities of the environment in the public interest. }\end{array}$ & & $\begin{array}{l}\text { ed capital assets, the need to } \\
\text { process; } \\
\text { roduction of similar goods; } \\
\text { international standards system } \\
\text { pportunities that eliminate the } \\
\text { ck." }\end{array}$ & \\
\hline Legal & & & E \\
\hline $\begin{array}{l}\text { Agenda 21, 1992, Rio de Janeiro; } \\
\text { The decision of the World Summit on Sustainable Development in } \\
\text { Johannesburg (South Africa), 2002; } \\
\text { The decision of the UN Conference on Sustainable Development } \\
\text { "Rio+20" 2012, Rio de Janeiro; } \\
\text { Organic 3.0; } \\
\text { Consideration of controversial issues based on the operating } \\
\text { principles of the functioning of the international trading system; } \\
\text { Establishment of the institutional environment necessary to achiev } \\
\text { the goals of green growth. }\end{array}$ & & $\begin{array}{l}\text { Implementation of the EaP GREEN project; } \\
\text { Implementation of the OECD provisions for measuring green } \\
\text { growth; } \\
\text { Process monitoring and evaluation with regard to green growth; } \\
\text { Requirements for increasing carbon and energy efficiency; } \\
\text { Increasing the efficiency of using materials while simultaneously } \\
\text { saving natural assets and improving the living standards; } \\
\text { Ecologization of small and medium business. }\end{array}$ & \\
\hline
\end{tabular}

\section{Sustainable development of agriculture}

Recently, FAO has developed elements of a common scheme and an approach that allows a more efficient and comprehensive solution to the problems of sustainable agricultural development. This approach helps to support the efforts already undertaken in the field of agricultural development, which has led to a significant increase in productivity, making possible the provision of food for the ever-growing population of the planet, with a relatively limited increase in agricultural land. However, transformational processes in different countries are distinct, they are often accompanied by social or environmental costs that prevent the achievement of a positive effect and endanger the very sustainability. Further transformation processes in the agrarian sector will continue to be based on increased productivity but particular attention is paid to the economic and environmental aspects of sustainability (Food and Agricultural Organization of the United Nationals, 2016).

It is worth noting that the concept of sustainable agriculture arose later, probably because of its specificity. The impetus for the development of this concept was the Brundtland Report (1987) and the United Nations
Conference on Environment and Development in Rio de Janeiro in 1992 (Raman, 2006; Zegar, 2005) and Rio+20. The concept of sustainable development in agriculture has its peculiarities since it is the most widespread and most important area of human activity, because:

- production is aimed at the satisfaction of the basic human needs;

- is the main user of rural areas;

- naturally and significantly affects the environment;

- takes the main place in the civilization development of interaction with the environment;

- performs complex functions: produces both food and industrial products, protects the environment and landscape, is the basic factor of the viability of the rural area, etc.

The complex nature of the concept depends on the numerous local natural conditions, on the system of soil cultivation, and other factors. According to Faber (Faber, 2010), these features can be generalized in the following short definition: "Sustainable agriculture provides an opportunity for simultaneous and harmonious achievement of economic, ecological, and social goals of agrarian production." 
Along with that, the transition to a "green" way of development requires special attention to the infrastructure of rural areas. Considering the longevity of the infrastructure, it is extremely important that the decision on its development is not focused on the use of technologies that are based on the intensive use of resources and cause the most severe pollution. Adequate infrastructure plays a providing role for other sectors of development, also affects the reduction of regional differences.

At the same time, the Ukraine-EU and MoldovaEU Association Agreements define the main tasks for improving the quality of life in rural areas in the direction of green growth, which is to increase the skills of peasants in maximizing the benefits of diversification of the rural economy, their understanding and involvement in processes of local development. The complex of measures to fulfil these tasks includes: stimulating the development of non-agricultural economic activity of rural communities; raising the level of knowledge and practical skills of rural residents in order to enable them to initiate and carry out certain activities; support for the development of local infrastructure, which provides the general conditions for the functioning of a diversified rural economy and increasing the level of access of the population to basic services (Heiets, 2016).

Consequently, given the fact that the course of green growth has the potential to support economic and social development and can provide conditions, under which natural assets can continue to provide material goods and services, on which the economy and the welfare of people depend to a large extent, it is the main goal of the green transformation of agricultural production. Moreover, "green" restructuring can bring a lot of positive results, which may be an impetus for the growth of the economy, in particular, the emergence of new sources of economic growth, increased productivity and innovation level, the creation of new jobs, and access to foreign markets, as well as new budget revenues.

It is important to note that the concept of green growth does not replace the concept of sustainable development but serves as a practical tool for achieving the goals of sustainable development. Both concepts are based on the principles of interaction between society and nature and are aimed at meeting the needs of not only modern but also future generations.

The generalization of the above allows highlighting the peculiarities of the concept and strategy of the green growth of the OECD:

- natural capital is considered as a factor of production, as productive capital, the restoration and expansion of which require investment;

- environmental policy is considered as an investment policy aimed at increasing the efficiency of the use of natural resources through the development and use of the up-to-date resource- and energy-efficient lowcarbon technologies;
- "green" activities and environmental innovations are designed to promote structural restructuring, increase productivity, capital, resources use, and support the transition to the technology of a new wave and infrastructure modernization;

- the close relationship between economic and environmental policies is ensured through the use of instruments such as fair pricing and taxation in order to stimulate resource conservation, introduce more rigorous but stimulating environmental standards and technical regulations, reform the system of farm subsidies, introduce an expanded system of indicators for assessing performance in indicated areas (Official site of the Ministry of Economic Development and Trade of Ukraine, 2016).

\section{Foundations for the transition to green growth}

The prerequisite for integration processes in Eastern European countries is to take into account the ecological importance of capital and implement basic and sectoral development goals through the prism of green growth.

The analysis of the regulatory framework for the transition to green growth (see Table 2) of the agrarian sector, in fact, indicates the need to use sufficiently differentiated instruments and their flexible application.

Despite the fact that all the countries of the Eastern Partnership with the EU support the transition to a green economy, at the national level, the green economy and sustainable development are enshrined as "fundamental principles" in a number of national development strategies, the interest in the principles of green economy in each country has its own priorities (see Table 3 ).

The Strategic Environmental Assessment (SEA) and Environmental Impact Assessments (EIA) are procedural tools that help target indicators in relation to green economy and other sustainable development issues to be integrated into strategic decision-making processes, in particular, at project level, thus so that the environmental and public health consequences are taken into account when making decisions. The SEA is conducted in relation to government policy plans, programs, and documents in accordance with the requirements of the UNECE Protocol on Strategic Environmental Assessment to the Espoo Convention (SEA Protocol) and the European SEA Directive (Ecologization of the economy in the EU Eastern Neighbourhood countries).

Indicators of Strategic Environmental Assessment and Environmental Impact Assessments allow determining the degree to which the state protects its natural environment. Each country, depending on the conditions in which it exists, has to prepare its coordinate system, which will help to monitor this work at the national level (Strategic protocol environmental assessment). 
Table 2

Adaptation directions of statutory regulation in Eastern European countries for the transition to green growth

\begin{tabular}{|c|c|}
\hline Country & Elements of internal support \\
\hline $\begin{array}{l}\text { 节 } \\
\text { 至 }\end{array}$ & $\begin{array}{l}\text { The concept of sustainable development has been taken into account in the Program of Strategic Development of the Republic } \\
\text { of Armenia for 2014-2025. The objectives of green growth are enshrined in a number of documents regulating sectoral policies, } \\
\text { such as the National Water Program and energy development strategies aimed at diversifying energy resources. }\end{array}$ \\
\hline 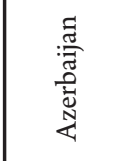 & $\begin{array}{l}\text { "Azerbaijan - 2020: Look into the Future" includes environmental tasks. Action Plan for Improving the Ecological Situation } \\
\text { and Efficient Use of Natural Resources for the Period of 2015-2020. In 2016, the Ministry of Economy presented the details } \\
\text { of a strategic "roadmap" aimed at diversifying the economy through the development of agriculture, small and medium-sized } \\
\text { enterprises. Draft laws on Strategic Environmental Assessment (SEA) and Environmental Impact Assessment (EIA). }\end{array}$ \\
\hline 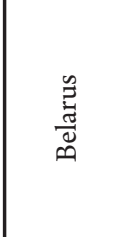 & $\begin{array}{l}\text { The National Strategy for Sustainable Socio-Economic Development for the period up to } 2030 \text { sets the goals of sustainable } \\
\text { development, envisages the introduction of a green economy. The Strategy for Environmental Protection of the Republic of } \\
\text { Belarus for the period up to 2025. The National Action Plan for the development of the green economy - the reorientation of } \\
\text { consumer behaviour towards more sustainable consumption patterns; development of environmentally sound physical capital } \\
\text { for sustainable production patterns, promotion of fair and green trade; promoting awareness of the benefits of sustainable } \\
\text { development. A new law on environmental expertise, SEA and EIA has been adopted, as well as bylaws on SEA and EIA. }\end{array}$ \\
\hline 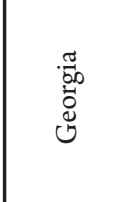 & $\begin{array}{l}\text { The EU-Georgia Association Agreement was signed in 2014, which came into force in 2016. The agreement covers the } \\
\text { objectives in relation to sustainable development and the environment and introduces a special trade regime through the } \\
\text { Agreement on Deep and Comprehensive Free Trade Area. The National Environmental Action Plan for the period of 2012- } \\
\text { 2016. In 2014, the government approved the Georgia-2020 Development Strategy, one of the most important goals of which is to } \\
\text { promote green growth. The Code on Environmental Assessment is submitted to the Parliament. }\end{array}$ \\
\hline$\frac{\widetilde{2}}{\overbrace{0}^{0}}$ & $\begin{array}{l}\text { Association Agreement and the Agreement on Deep and Comprehensive Free Trade Area with the EU (2014), which entered } \\
\text { into force in 2016. Moldova committed itself to actively pursue structural reforms and harmonize its legislation with the EU } \\
\text { acquis communautaire, the Moldova-2020 National Development Strategy, Moldova Environmental Strategy for 2013-2023, } \\
\text { the National Strategy for Sustainable Development of Agriculture for 2008-2015, which include goals of the green economy. } \\
\text { In 2015, the development of "Roadmap" for the transition to a green economy and sustainable development. First and second } \\
\text { amendments to the Espoo Convention have been adopted. }\end{array}$ \\
\hline 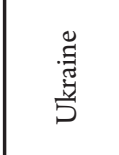 & $\begin{array}{l}\text { The principles of sustainable development and the green economy are reflected in the Action Plan on Implementation of the } \\
\text { EU-Ukraine Association Agreement and the EU Free Trade Agreement and the Ukraine- } 2020 \text { Sustainable Development } \\
\text { Strategy (integrated package of tasks aimed at the green transformation of the economy). Parliament of Ukraine adopted } \\
\text { the Law "On Strategic Environmental Assessment". }\end{array}$ \\
\hline
\end{tabular}

Table 3

The main vectors of the implementation of green growth in the Eastern Partnership countries

\begin{tabular}{|c|c|}
\hline Country & Measures \\
\hline $\begin{array}{l}\text { Armenia, Georgia, } \\
\text { Azerbaijan, Moldova, } \\
\text { Belarus, and Ukraine }\end{array}$ & $\begin{array}{l}\text { Reform of SEA (Strategic Environmental Assessment) and EIA (Environmental Impact Assessment) legal and } \\
\text { institutional frameworks; } \\
\text { Development of National Green Economy Strategy; } \\
\text { Expansion of trade opportunities in international markets for organic agricultural products; } \\
\text { Increasing access to funding sources for green investment; } \\
\text { Improvement of market incentives to environmentalize goods; } \\
\text { Environmentalization of small and medium-sized enterprises through the Strategy for the Development of Small } \\
\text { and Medium-Sized Enterprises. }\end{array}$ \\
\hline $\begin{array}{l}\text { Belarus, Moldova, } \\
\text { Ukraine }\end{array}$ & $\begin{array}{l}\text { Quantitative industry analysis has been carried out demonstrating the environmental, economic, and social } \\
\text { benefits of the transition to a green economy. }\end{array}$ \\
\hline $\begin{array}{l}\text { Belarus, Moldova, } \\
\text { Georgia }\end{array}$ & The development of national strategies or action plans for the green economy has begun. \\
\hline $\begin{array}{l}\text { Armenia, Azerbaijan, } \\
\text { Moldova, and Ukraine }\end{array}$ & Development of green growth indicators. \\
\hline Moldova i Ukraine & $\begin{array}{l}\text { Enforcing in the environmental legislation, prepared on the basis of the analysis, recommendations on reforming } \\
\text { taxes on products. }\end{array}$ \\
\hline $\begin{array}{l}\text { Armenia, Georgia, } \\
\text { Moldova, and Ukraine }\end{array}$ & $\begin{array}{l}\text { Policies and regulatory instruments aimed at environmentalizing small and medium-sized enterprises have begun, } \\
\text { and the results of the analysis of increasing the environmental efficiency of small and medium-sized enterprises } \\
\text { have been introduced into the development strategies of small and medium-sized enterprises. }\end{array}$ \\
\hline
\end{tabular}


The experience of realization of a roadmap to a resource-efficient, competitive green economy in the European Union countries shows the real possibilities of resource saving, increase of business competitiveness, attraction of additional sources of economic growth, and creation of jobs. Thus, the results of surveys of business companies in the EU show that measures for increasing resource efficiency at all links of the value chain can reduce the European Union's need for raw materials by $17-24 \%$ by 2030 compared to 2013 and increase EU countries' GDP by about 3.9\% due to the creation of new markets and products (European Commission, 2014).

However, the typical disadvantages of modernity include the absolutisation of economic growth and its traditional indicators. It seems logical to evaluate the problem in another aspect. In these statements, economic growth is usually identified with GDP growth, profit maximization, financial flows, and other financial indicators, and the quality of growth and its costs (environmental and social) are usually ignored. It is widely recognized in the world that GDP is an inadequate indicator to reflect many important aspects of socio-economic development, including social and environmental factors.

An important feature of all six countries of the Eastern Partnership with the EU is that since the 2000s, GDP has grown, albeit to different degrees (Figure 1). Despite the fact that all countries suffered significantly from the economic crisis of 2008-2009, most of them were able to recover, integrate into the global economy, and establish strong trade relations with the European Union.

The growth of the service sector has led to a reduction in the burden on the environment. Assessing the situation in figures, despite the fact that, in general, the share of agriculture in the economy has declined (see
Table 4), it continues to play an important role in the structure of GDP and employment in some countries, thus making a significant impact on land and water resources (Greening the economy in the EU Eastern Neighbourhood countries).

Table 4

Structure of GDP of the Eastern Partnership countries by economic sectors (2015)

\begin{tabular}{|l|c|c|c|}
\hline \multicolumn{1}{|c|}{ Country } & Agriculture & Industry & Services sector \\
\hline Armenia & 19 & 29 & 52 \\
\hline Azerbaijan & 7 & 37 & 56 \\
\hline Belarus & 8 & 40 & 52 \\
\hline Georgia & 9 & 25 & 66 \\
\hline Moldova & 14 & 18 & 68 \\
\hline Ukraine & 24 & 26 & 60 \\
\hline
\end{tabular}

If the gross domestic product (GDP) took into account the depletion of natural capital, the net GDP figures in the countries would be much lower. Permanent degradation of the environment, high levels of emissions leading to climate change, inefficient use of energy, outdated and non-economic production technologies, rising losses and water scarcity, especially in agriculture, as well as costs associated with the listed problems, point to the need to intensify actions in the field of integrating environmental objectives into the sectoral economy (Organization for Economic Cooperation and Development).

\section{Importance of the monitoring of the green growth process}

The OECD approach to assessing the progress of green growth was presented in the 2011 Report "Towards Green Growth: Monitoring Progress”(OECD, 2014). It describes the conceptual measurement methodology,

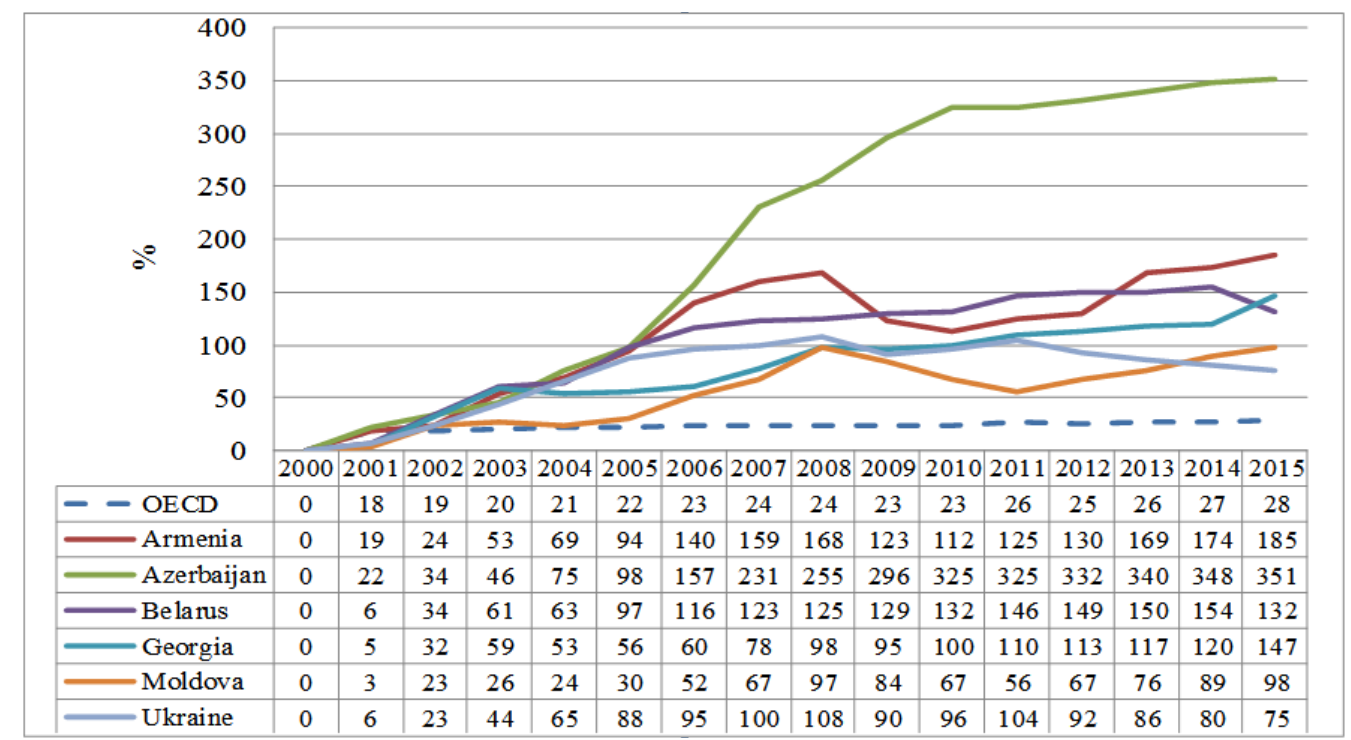

Figure 1. Changes in the real GDP of the Eastern European countries (in percent compared to 2000) 
which combines the main parameters of green growth with the basic principles of accounting and the model "pressure-state-reaction", which is used in environmental reporting and expertise (EaP Green, 2016).

In addition, particular attention should be paid to the basic OECD green growth dominants, in particular: strategic policy planning, green growth indicators, environmentally harmful subsidies, market incentives for organic products, sustainable government procurement, access to green investment financing, and the greening of small and medium-sized businesses.

To monitor the green growth process, the OECD proposes to use five groups of indicators, four of which cover different sectors of the green economy, and the fifth - macroeconomic indicators of national development: the ecological and resource efficiency of the economy; a base of natural assets; environmental aspects of life quality; economic opportunities and answers of the policy; socio-economic context and characteristics of economic growth.

Indicators of environmental and resource productivity describe key aspects of the transition to a low-carbon and resource-efficient economy. In countries rich in natural resources, their quantitative assessment is not given enough attention. However, in these countries, the results of economic development and the quality of growth are increasingly dependent on the natural environment, which simultaneously is a provider of raw resources (energy, water, materials) and an absorber of pollution and waste. Efficient use of primary resources, minimization of waste, their processing and transformation into a resource increase the profitability of business (upon condition that resource prices do not distort competition) and slow down the depletion of the base of natural assets.

To ensure the long-term stability of the country's development, it is necessary that the natural assets base fulfils not only resource but also absorption, service functions (biodiversity), and the load on the natural environment does not exceed its capacity. For this purpose, indicators of actual reserves and flows of renewable (water, forest) and non-renewable resources (mineral resources) are monitored.

There is a direct link between the state of the environment and the quality of human life. It should be monitored by using indicators of the environmental quality of life that reflect the health and safety risks, the availability of amenities and eco-system services.

Indicators of economic opportunities and policy measures assess the performance of the state in support of green growth: investment in green activities and technology development, stimulating eco-innovation and green procurement, reforming subsidies and prices.

Indicators relating to the socio-economic context and characteristics of economic growth are used to reflect the results of the green transformation at the macro level, including the attraction of additional sources of growth, changes in the economic structure, employment and labour markets, increased incomes, and the competitiveness of business and the economy as a whole (Ministry of Economic Development and Trade of Ukraine, 2016).

The achievements of the Eastern Partnership countries on the way of green growth are determined on the basis of the Environmental Performance Index (The Environmental Performance Index, 2018) (Table 5), which characterizes their place in the field of management of natural resources and their rational use. In general, in 2018, Switzerland is recognized as the leader in terms of environmental efficiency.

Table 5

Environmental Performance Index

of Eastern European countries for 2018

\begin{tabular}{|l|c|c|c|}
\hline Country & Rating & $\begin{array}{l}\text { Environmental } \\
\text { Performance Index }\end{array}$ & $\begin{array}{l}\text { Changes over } \\
10 \text { years, \% }\end{array}$ \\
\hline Armenia & 63 & 62,07 & $+13,19$ \\
\hline Azerbaijan & 59 & 62,33 & $+18,10$ \\
\hline Belarus & 44 & 64,98 & $+3,77$ \\
\hline Georgia & 94 & 55,69 & $+11,77$ \\
\hline Moldova & 112 & 51,97 & $+9,09$ \\
\hline Ukraine & 109 & 52,87 & $+25,38$ \\
\hline
\end{tabular}

The list of the main (in agriculture) green growth indicators (the OECD offers 60 indicators in total), which are in line with the declared objectives of the development of the Eastern Partnership countries and can be used to assess the effectiveness of the green growth policy. On an ongoing basis, it is especially important to monitor environmental and resource productivity, multi-factor productivity, land use dynamics, life expectancy, financing of R\&D important for reducing energy and resource consumption, waste and emissions, and also the structure of energy, materials, water consumption; $\mathrm{CO} 2$ emissions in terms of types of economic activity.

The analysis carried out makes it possible to argue that the green transformations of the agrarian industry make it necessary to include the environmental factor in the system of basic socio-economic development indicators. Failure to take into account the environmental factor in the approval of development strategies is largely related to the lack of country development, cost reflection of natural capital, and environmental degradation in traditional indicators. Existing traditional macroeconomic indicators (GDP, income per capita, budget indicators etc.) ignore environmental degradation. The growth of these indicators in countries today is based on technogenic natural resource-intensive development. Therefore, this creates the possibility of a sharp deterioration of economic indicators in the future in the case of depletion of natural resources and environmental pollution. Among recent works in the area of developing new approaches to measuring 
development, The Measurement of Economic Performance and Social Progress by J. Stiglitz and A. Sen should be noted (Stiglitz, 2009). In particular, this report notes that the modern system of measuring socioeconomic processes is imperfect. GDP is not an ideal indicator for measuring welfare since it does not cover various social processes, changes in the environment, some of the phenomena that are commonly referred to as "sustainability" of development.

A characteristic feature in this regard is the report of the European Environment Agency (2007), which widely uses indicators for the analysis and forecast of the environmental situation in Europe (European Environment Agency, 2007). The key point in these approaches is an attempt to take into account the damage from environmental pollution and the depletion of natural resources at the macroeconomic level, to adjust ecologically the basic economic indicators of development. However, besides, indicators of accumulated damage (pollution and waste), resource depletion (which in the long run is not compensated for by the exploration of new reserves), the impact of environmental pollution on human health, landscape degradation, assessment of ecosystem services (forest, water) are necessary.

\section{Conclusions}

The use of own and accumulated experience of other countries in the direction of using levers to stimulate green growth allows drawing certain conclusions regarding the response of the agrarian sector of economies of the Eastern Partnership countries. The starting point of such a forecast is the general assessment of the state of the macroeconomic system and hierarchical levels of its structure, in which the usual parameters of functioning are transformed. The rapid growth of international commodity exchange is accompanied by increased control over the state of the environment and the prevention of possible damage from uncontrolled interference. Limits and barriers to developing green growth indices and indicators are largely determined by the lack of necessary economic, social, and environmental information. Nowadays there is a paradoxical situation in countries where many key indicators of green growth are included in the most important documents of the country's development but they are not published in official statistical reference books, which complicates their use in decision-making processes at all levels and information of the public. For widespread use of green growth indicators at all levels, it is necessary to include these and similar indicators in state statistics of the countries and broad social circulation as soon as possible. Among these indicators, the following are proposed:

- the number of people living in contaminated territories (cities);

- different indicators of natural resources intensity and pollution intensity;

- indicators of soil degradation in agriculture (growth of eroded lands, imbalance of soil organic matter);

- the number of people using drinking water that does not comply with hygiene standards (million people);

- agricultural land use efficiency indicator (ecological and resource productivity, multi-factor productivity, land use dynamics).

The passive position of countries in relation to the use of green growth indicators can forever form the raw material orientation of the economy. However, using an expanded system of green growth indicators or a system of core/key indicators will allow assessing progress towards sustainable development according to several key indicators in strategic planning.

The practical application of green growth indicators in statistical accounting corresponds to the declared program development goals of countries in the direction of green growth and promotes: increasing the competitiveness of small business forms in rural areas by reducing energy consumption and minimizing the amount of generated waste; the diversification of rural economies, and the access of small business forms to foreign markets in niche cultures (the development of new markets and the creation of new jobs); reduction of risks to economic growth, and the danger of conflicts caused by the lack of resources; effective development of organic production.

\section{References:}

EaP Green (2016). Otsenka zelenoy transformatsii ekonomiki: rukovodstvo dlya stran vostochnogo partnerstva YES. [Assessment of the Green Transformation of the Economy: A guide for the Eastern Partnership countries of the EU]. Paris. Retrieved from: http://www.green-economies-eap.org/ru/resources/EaP\%20 GREEN_GGI\%20 Guide_clean_RUS_Final.pdf

Ecologization of the economy in the EU Eastern Neighbourhood countries. Retrieved from: http://www.green-economies-eap.org/

European Commission (2014). Communication from the Commission to the European Parliament, the Council, the European Economic and Social Committee and the Committee of the Regions. Brussels. Retrieved from: http://ec.europa.eu/environment

European Environment Agency (2007). The Pan-European environment: glimpses into uncertain future. Copenhagen.

Faber, A. (2010). Ocena stopnia zrównoważenia rolnictwa w Polsce w różnych skalach przestrzennych. Studia i Raporty IUNG-PIB. R. Pudełko, K. Filipiak, M. Borzęcka-Walker, R. Borek, J. Jadczyszyn, J. Kozyra, K. Mizak, Ł. Świtaj. 
Food and agricultural organization of the United Nationals (2016). Rabota FAO v prodovolstvennom i selskokhozyaystvennom sektore $\mathrm{v}$ sootvetstviye so Strategicheskoy ramochnoy programmoy [FAO's work in the food and agriculture sector in line with the Strategic Framework]. Retrieved from: http://www.fao.org/3/ a-mr233r.pdf.

Heiets, V. M., Ostashko, T. O. (2016). Implementatsiya Uhody pro asotsiatsiyu mizh Ukrayinoyu ta YES: ekonomichni vyklyky ta novi mozhlyvosti: naukova dopovid [Implementation of the Association Agreement between Ukraine and the EU: economic challenges and new opportunities: scientific report]. Kiev: National Academy of Sciences of Ukraine, Institute of Economics and Prognosis of the National Academy of Sciences of Ukraine.

Stiglitz, J. E., Sen, A., Fitoussi, J.-P. (2009). Report by the Commission on the Measurement of Economic Performance and Social Progress. Retrieved from: http://www.stiglitz-sen-fitoussi.fr/

Kurinets, L. Ye., Kharichkov, S. K. (2007). Problemy proizvodstva ekologicheski chistoy produktsii v APK: mezhdunarodnyy i natsionalnyy aspekty [Problems of production of environmentally friendly products in the agricultural sector: international and national aspects]. Odessa: EPREE.

Kvasha, T. K., Musina, L. A. (2015). Vymiryuvannya zelenoho zrostannya v Ukrayini: kontseptsiyi, systemy indykatoriv, dosvid formuvannya ta perspektyvy zastosuvannya [Measurement of green growth in Ukraine: concepts, indicator systems, experience of formation and prospects of application]. Kiev: UkrISTEI.

OECD (2014). «The OECD green growth measurement framework and indicators», in Green Growth Indicators 2014, OECD. Retrieved from: http://dx.doi.org/10.1787/9789264202030-4-en

Official site of the Ministry of economic development and trade of Ukraine (2016). Dopovid pro zelenu transformatsiyu v Ukrayini na osnovi pokaznykiv zelenoho zrostannya OESR [Report on green transformation in Ukraine based on OECD green growth indicators]. Retrieved from: http://www.me.gov.ua

Organization for economic cooperation and development. "Zelenyy" rost i prirodookhrannoye upravleniye $\mathrm{v}$ stranakh Vostochnoy Yevropy, Kavkaza i Tsentralnoy Azii ["Green" growth and environmental management in the countries of Eastern Europe, the Caucasus and Central Asia]. Retrieved from: https://www.oecd.org/env/ outreach/48876138.pdf

Raman, S. (2006). Agricultural sustainability: principles, processes, and prospects. food products press, an imprint of the Haworth Press, New York. London-Oxford.

Strategic protocol environmental assessment. Facts and benefits of applying the United Nations Economic Commission for Europe. Retrieved from: http://www.unece.org

The Environmental Performance Index (2018). Retrieved from: https://gtmarket.ru/ratings/environmentalperformance-index/info

Zegar, J. S. (2005). Koncepcja badań nad rolnictwem społecznie zrównoważonym [The concept of research on socially sustainable agriculture]. Warszaw: IERiGŻ. 